\title{
INNOVATIVE METHODS OF TEACHING IN A LARGE EngineEring Classroom EnvironMEnT
}

\author{
A. Mohamed \\ Faculty of Engineering and Applied Science, Memorial University, St. John's, NL, A1B $3 X 5$ \\ amohamed@mun.ca
}

\begin{abstract}
Many instructors in engineering faculties believe large classes are not as effective or interactive as teaching small classes. When engineering faculties have increased their student intake due to enrolment growth, this has often led to larger classes. This paper discusses the challenges associated with teaching large engineering class sizes.

Innovative techniques and solutions are discussed to enable teaching of large classes to become effective and productive like teaching smaller classes.

The paper will describe various methods so that the skills to manage and improve the learning environment in large classes can be adopted as effective alternatives to small class sizes.
\end{abstract}

Keywords: large class; technology; teamwork; teaching; learning.

\section{INTRODUCTION}

Teaching of large classes requires dedication, concentration, determination, excellent communication, good preparation, creativity, innovation and patience. It is a challenging task that has been examined in articles in a number of journals of engineering education, including the Journal of International Engineering Education (IJEE), American Society for Engineering Education (ASEE), and recently, the Canadian Engineering Education Association (CEEA), recently founded in 2009. The ratio of large to small class size varies with the type of institution and country. In some institutions, the student-teacher ratio is up to 200:1. Large engineering institutions are facing similar difficulties with ratios of 100:1 or more. Recent studies reported that a class of 40 students or more can be considered a large class size, as reported by Benbow [1]. Such large class sizes are typical in many engineering schools, even double as large, and occasionally, triple the 40 student limit.

There are different views about the effects of large class sizes in engineering institutions. The reality, however, is that large class sizes present challenges to ensuring a good quality of teaching-learning in engineering institutions.

\subsection{Teaching in a Large Class}

In many ways, large class sizes can have negative impacts on learning that are especially significant in terms of teaching time and class management. Research has shown that teachers in larger classes tend to devote less time to actually teaching and combined reading / writing tasks underestimate the time required prior to class for advanced preparation [2]. Other studies indicate that teachers in smaller classes are more likely to be able to cover a wider range of lecture topics in the prescribed course material [3].

Large classes require more effort and demand on the teacher's ability to deal with time and organization, and hence require extra time devoted to teaching. For instance, in large classes, teachers become more concerned about how they will finish tasks and exercises instead of concern for the learning outcomes from teaching. As a result, there is less time for actual teaching and exercises and less use of the time given to teach in a 50 minute class, for example, because there are distractions from student enquiries during class time [2-4]. Large classes are often more noisy and it can sometimes be difficult to manage such noise relative to a small class [2].

\subsection{Student in a Large Class}

Students can interact and engage in a large class, as well as socially and academically with teachers. A friendly learning environment can be developed if the teacher is able to proceed and manage large classes effectively [5]. Finn et al. [5] have reported that if students are in a small class, they become more engaged than a large class, both socially and academically.

Finn et al. [5] also reported that student academic outcomes increase in small classes and students are normally more involved and interactive. The author also found that student attendance is more consistent in a small class than a large one and, in addition, there is an increase in their interest and enjoyment of the classroom experience. In part, this may occur because the instructor is able to recognize students by name as compared to a large class where many students remain anonymous. In a small class, the teacher can more readily accommodate 
different learning styles. Student passivity is also less pronounced in a small class [6-9].

Thus, teaching large classes in engineering is a significant challenge. These observations are discussed based on a number of courses taught by the first author in different engineering schools.

This paper also discusses some innovative methods for enhancing teaching in large engineering classes and offers a number of suggestions and recommendations.

\section{METHODOLOGY}

The student-teacher ratio (STR) of the courses under consideration exceeds $80: 1$. This is about double the minimum ratio of 40:1 [1] above which a class can be considered large. Figure 1 shows a schematic of teaching methods for large engineering classes.

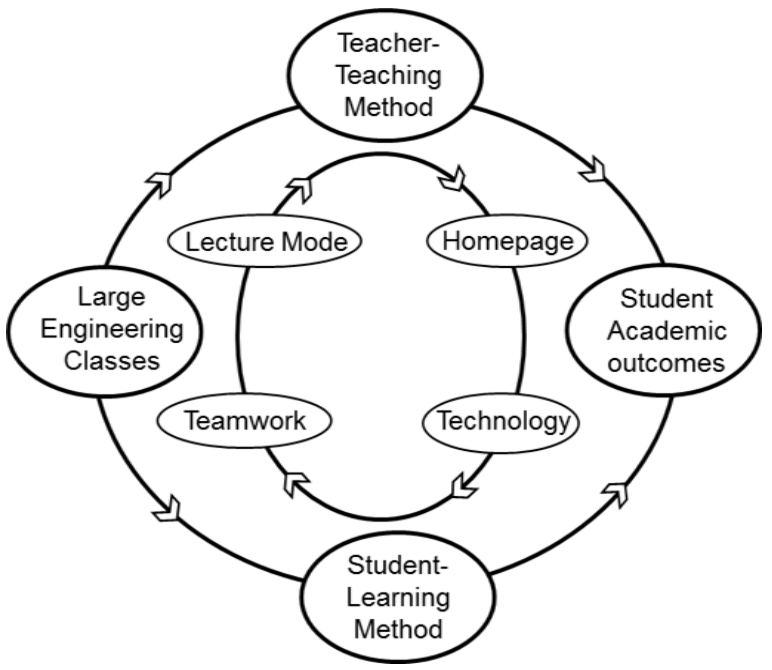

Fig. 1. Schematic of teaching in a large engineering classroom.

\subsection{Lecture Mode}

Although many teachers use PowerPoint slides for lecture presentations, there are others who teach large classes using transparency slides with an overhead projector, and/or a black/white board for writing or drawing graphs. These traditional tools can negatively

impact the learning process in large class sizes, i.e., students lose interest and become passive.

In large classes, students tend to hesitate to speak to a teacher on issues such as a small font size on an overhead transparency, projector poorly focused, unclear hand writing, and poorly drawn sketches. These issues are most problematic for students who sit in the back rows in large classes. Hence, PowerPoint is used for a number of reasons. With PowerPoint, one has the capability of readily altering font size, etc. in response to student reactions and providing spontaneous examples and explanations to clarify and/or expand on topics.

PowerPoint also has tools for creating more dynamic, interactive and colorful presentations for a large classroom that improves attentiveness. PowerPoint lecture presentations from pre-made slides saves time of writing on a whiteboard and can be readily rearranged. Students often find that a PowerPoint lecture presentation mode is easier to follow and understand as compared to more traditional modes such as overheard and white/black board.

Some teachers accompany the PowerPoint with written notes so that students can concentrate on the PowerPoint rather than writing down notes written on the board.

From the first author's experience, it is easier to include actual graphs and images obtained from research that are related to the lecture topic and thereby personalize and expand the concept in the lecture.

In this way, students have not deemed the pace of PowerPoint lecture presentations as too fast. The PowerPoint presentation can enable the instructor to spend more time interacting with students on the lecture topic through the medium of PowerPoint slides than by other, more traditional means.

\subsection{Course Homepage}

In order to have dynamic, interactive and effective teaching in a large class, it is important to create out-ofclass communication and relations between students and the teacher. One valuable means of this is to create a homepage for information about the course, for reinforcing instructions that have been communicated in the classroom, and for uploading notes and PowerPoint slides. After a PowerPoint lecture, a copy of the presentation can be converted to a PDF file.

At Memorial University, on the homepage entitled D2L, Desire to Learn, students go to homepage: https://online.mun.ca/index.asp and sign in to use a university username and password. The lecture notes online are well received as supportive to the learning environment, together with other information about the course such as important dates. The homepage resource motivates students to interact with the teacher during the lecture in a large class and thus improve communication.

\subsection{Team Name and Team Tag}

In large classes, students tend to remain anonymous. One useful way to improve this situation is to divide the class into teams for in-class discussions, for mutual support, and for team projects and/or presentations. For improved student interaction and interest, the teacher can create a competition between teams to stretch and 
challenge students who would remain anonymous in the case of a traditional teaching method in large engineering classrooms. For example, the teacher may select a number of topics from course subjects and allow teams to compete for a best presentation on those topics at the end of the term, with an award given for the best presentation for each topic and among all topics (see Fig. 2).

Teams are given a name and a name tag to be posted at their seat location in the classroom. Each team returns to the same location with their name tag at the beginning of each class: in an engineering class it increases interest if the team names are those of famous engineers, e.g. Team Faraday.

This team concept assists students to finish on time. Furthermore, the team name, team tag and fixed location in a large engineering classroom help the teacher to remember student names. Students are highly appreciated, recognized and encouraged when the instructor calls students by their names. In addition to team discussions, there can also be team presentations to the class in which two teams briefly share their ideas on the question.

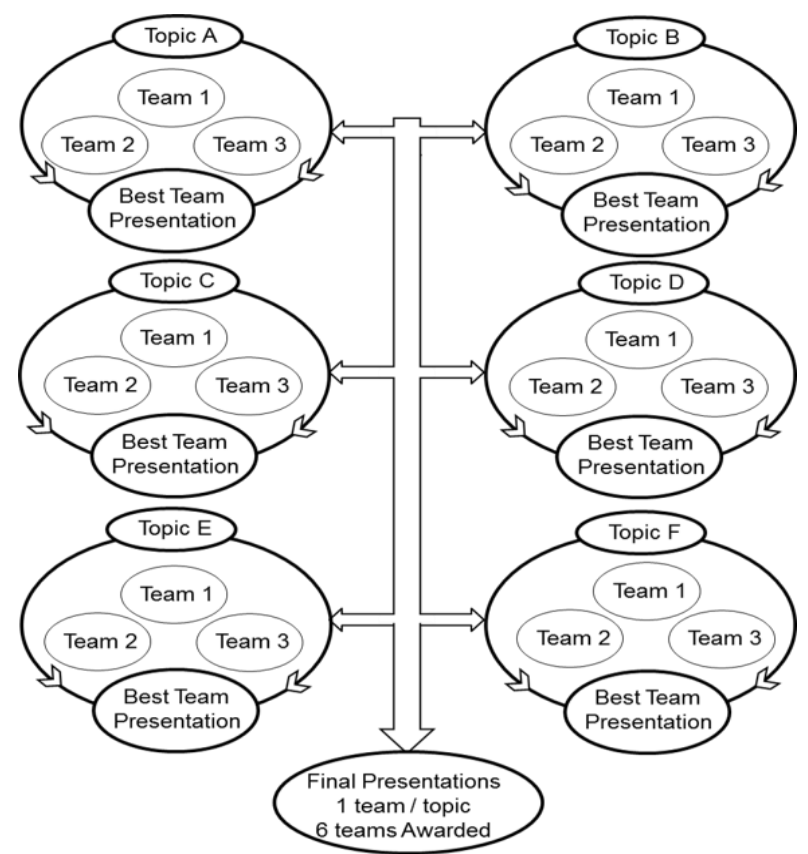

Fig. 2. Schematic showing teamwork activities in a large engineering classroom

\subsection{Technology}

Activities in large classes such as lecturing and classroom discussions are a challenge to facilitate without technology to help create a flexible learning environment that can support teamwork within a large engineering class. Technology can also provide the opportunity for the teacher to approach the students and have individual conversations during class. Suggestions are also given in regards to assessment of the performance of engineering students in large class courses.

The author has found the following tools essential for teaching a large class in an engineering institution: data projectors, overhead projectors, projection screens, sound system, computer and DVD player, control panel and wireless microphones for teacher and students for classroom team discussions. The advantages of electronic slides are that they can be prepared in advance and they improve the delivery of the presentation. Furthermore, it is also important to have a successful and comfortable teaching environment for large classes for both students and the instructor.

\section{ADJUSTED MARKING FOR EACH GROUP MEMBER IN TEAM-BASED WORK}

Teachers in engineering schools with large classes are faced with either taking into account the effort of each individual in a team project or a team presentation by providing an individual grade, or not recognizing the full effort of individuals in a team that can be variable and thus giving the same grade to each student in a team. While any method for adjusting grades has an element of subjectivity, the awareness of students that such adjustments will occur acts as a disincentive for other team members. Sometimes a conscientious student will put in extra effort despite an "unbalanced" team in an effort to secure a good grade.

The following method has been used in one course with a large class and has generally been well received by the students, especially when some team members have found themselves putting in much more additional time and effort to make up for less than required effort by one or more other team members. When the team project is completed, each team member provides the teacher with how he/she would divide a "bonus" of \$100,000 among the other team members. The results are not, of course, distributed to the team.

The following calculations led to an adjusted grade for each team member.

\section{- Correction Factor $(C)$}

$\mathrm{C}=(\mathrm{A}-\mathrm{B}) / \mathrm{B}$, where $\mathrm{A}=$ average bonus received by student, and $\mathrm{B}=$ expected bonus.

\section{- Adjusted Grade (AG)}

$\mathrm{AG}=\mathrm{G}+\mathrm{C}(\mathrm{G}-50)$, where $\mathrm{G}=$ grade of team project $(\%)$ and $\mathrm{C}=$ correction factor. 
$\checkmark$ Note 1: The lowest a student's grade can be reduced to is $50 \%$.

$\checkmark$ Note 2: A cut-off of $100 \%$ is set for the maximum possible adjusted grade.

$\checkmark$ Note 3: It is assumed, based on experience, that no team project will receive a team mark, $G$, of less that $50 \%$. If this happens, no correction factors are calculated.

\section{- Example 1:}

$\mathrm{Jim}$ is in a team of four who receive a grade, $\mathrm{G}$, of $80 \%$ for their team project. Jim is given an average bonus from his three team members of $\$ 31,000$. The expected bonus is $\$ 100,000 / 3$ or $\$ 33,333$.

Therefore, the correction factor, $C$, is $(30,000$ $33,333) / 33,333=-0.1$.

Jim's grade, $A G$, will be reduced to $A G=G+C(G-50)=$ $80+(-0.1)(80-50)=77.0 \%$.

\section{- Example 2:}

Karen is in a team of three who receive a grade, G, of $75 \%$ for their team project.

Karen is given an average bonus from her three team members of $\$ 60,000$.

The expected bonus is $\$ 100,000 / 2$ or $\$ 50,000$.

Therefore, the correction factor, $C$, is $(60,000$ $50,000) / 50,000=0.2$.

Karen's grade, AG, will be increased to $A G=\mathrm{G}+\mathrm{C}(\mathrm{G}-$ $50)=75+(0.2)(75-50)=80.0 \%$

The assignment of this task is more than a way of adjusting for work effort in the team but also places the students in a situation of trust so as to act fairly and give the most serious consideration to the contribution of each team member. In the author's experience, this has increased the students' appreciation of the course instruction because he/she has made an attempt to provide some correction to an unfair situation when team members do not pull equal weight.

\section{STUDENT RESPONSE}

As a quantitative way of evaluating a student's attitude towards methods developed for teaching a large engineering class, a short questionnaire can be filled in by students. Sample results are shown in Table 1. The average score for each question is shown in the last column.
Table 1: Results of student response

\begin{tabular}{|c|c|c|}
\hline \multicolumn{3}{|c|}{$\begin{array}{l}\text { Table 1: Results of student response } \\
\text { "1" is strongly disagree, " } 5 \text { " is strongly agree }\end{array}$} \\
\hline 1 & $\begin{array}{l}\text { I liked the PowerPoint approach of } \\
\text { lecture slides as compared to other } \\
\text { lecture modes. }\end{array}$ & 4.5 \\
\hline 2 & $\begin{array}{l}\text { The PowerPoint approach to lectures } \\
\text { provides more opportunities for a variety } \\
\text { of information and content, e.g. graphics, } \\
\text { case histories, etc. than other presentation } \\
\text { modes. }\end{array}$ & 4.5 \\
\hline 3 & $\begin{array}{l}\text { PowerPoint slide font size, font type and } \\
\text { contrast between background and text } \\
\text { was clear and therefore helped engage } \\
\text { lectures more effectively. }\end{array}$ & 4.7 \\
\hline 4 & $\begin{array}{l}\text { Team discussions were valuable because } \\
\text { they exposed me to different } \\
\text { perspectives. }\end{array}$ & 4.2 \\
\hline 5 & $\begin{array}{l}\text { Series of lecture notes in PDF, series of } \\
\text { video related lecture notes, and other } \\
\text { important information on course related } \\
\text { notes are well managed and available } \\
\text { online in a course Homepage in case I } \\
\text { miss lecture or video. }\end{array}$ & 4.8 \\
\hline 6 & $\begin{array}{l}\text { Although my course is a large class size, } \\
\text { the level of student interaction between } \\
\text { student to student and between student to } \\
\text { teacher was very effective. }\end{array}$ & 4.6 \\
\hline
\end{tabular}

\section{CONCLUSIONS}

This paper examined some methods for enhancing teaching large engineering classes in a way as to allow students to experience some of the characteristics of a small engineering class and increase student interaction and student-teacher interaction. There was some evidence presented that a large engineering classroom environment can be made more dynamic, interactive, enjoyable and open to student engagement. For success in teaching large classes, there should be an advanced plan or roadmap of teaching and learning methods to be used - when, where, and how.

Significant differences in outcomes between teaching methods have been found in past studies (CEEA 2013; Paper 128). Teaching large classes can be as effective as a small class. The key to success in a large class is class management, lecture mode, technology embedded in the large class and team name / tag. If the instructor of a large class is well prepared prior to the start of class, students will receive better teaching than students in small classes, because the large class size has similarities to a conference where participants from different backgrounds 
and different experiences benefit from each other's knowledge.

\section{Acknowledgements}

Financial support from the Natural Sciences and Engineering Research Council of Canada (NSERC) is gratefully acknowledged.

\section{References}

[1] Benbow, Jane, Adela Mizrachi, Dan Oliver, and Laisha Said-Moshiro. "Large Class Size in the Developing World: What Do We Know and What Can We Do?" American Institute for Research: Educational Quality Improvement Program, 2009.

http://www.equip123.net/docs/E1-LargeClassrooms.pdf

[2] Wilson, Valerie. "Does Small Really Make a Difference? A review of the Literature on the Effects of Class Size on Teaching Practice and Pupils" Behavior and Attainment, Scottish Council for Research in Education, SCRE Research Report; 107, 2006.

[3] Holloway, H. John. "Do Smaller Classes Change Instruction?" Educational Leadership, vol. 59, no. 5, pp. 91- 92. 2002.
[4] Ehrenberg, G. Roland., Brewer, J. Dominic., Gamoran, Adam, and J. Douglus Willms. "Class Size and Student Achievement" Psychological Science in the Public Interest, vol. 2, no. 1, pp. 1-30. 2001.

[5] Jeremy D. Finn, Gina M. Pannozzo and Charles M. Achilles. "The "Why's" of Class Size: Student Behavior in Small Classes" Review of Educational Research, Published on behalf of American Educational Research Association, vol. 73, no. 3, pp. 321-368, 2003.

[6] Blatchford, Peter and Mortimore. "The issue of class size in schools: What can we learn from research?" Oxford Review of Education, vol. 20, no. 4, pp. 411-428. 1994.

[7] Cooper, M. Haris. "Does Reducing Student-To-Instructor Ratios Affect Achievement?" Educational Psychologist, vol. 24, no. 1, pp. 79-98. 1989.

[8] Harder, Heather. "A critical Look at Reduced Class Size" Contemporary Education, Information Analyses, vol. 62, no. 1, pp. 28-30, Fall 1990.

[9] Pasigna, L. Aida. "Tips on How to Manage a Large Class" Arlington, VA: Institute for International Research, Improving Educational Quality Project. 1997. 